\title{
RelA/NF- $\kappa$ B recruitment on the bax gene promoter antagonizes p73-dependent apoptosis in costimulated T cells
}

\author{
R Cianfrocca ${ }^{1}$, M Muscolini ${ }^{1}$, V Marzano ${ }^{1}$, A Annibaldi ${ }^{1}$, B Marinari ${ }^{2}$, M Levrero ${ }^{3,4}$, A Costanzo $0^{\star 2,4}$ and L Tuosto ${ }^{*, 1}$
}

The balance between antiapoptotic and proapoptotic proteins of the Bcl-2 family is critical in determining the fate of T cells in response to death stimuli. Proapoptotic genes, such as bax, are generally regulated by the p53 family of transcription factors, whereas NF- $\kappa$ B subunits can activate the transcription of antiapoptotic Bcl-2 members. Here, we show that CD28 activation protects memory $T$ cells from irradiation-induced apoptosis by both upregulating $b c l-x L$ and inhibiting bax gene expression. We found that $\mathrm{p} 73$, but not $\mathrm{p} 53$, binds to and trans-activates the bax gene promoter in irradiated T cells. The activation of RelA/NF- $\kappa \mathrm{B}$ subunit in CD28 costimulated T cells and its binding onto the bax gene promoter results in suppression of bax transcription and decrease in both $\mathrm{p} 73$ and RNA polymerase II recruitment in vivo. RelA recruitment on the bax gene promoter is also accompanied by the lost of $\mathrm{p} 300$ binding and the parallel appearance of histone deacetylase-1-containing complexes. These findings identify RelA/NF- $\kappa$ B as a critical regulator of T-cell survival by affecting the balance of $\mathrm{Bcl}-2$ family members.

Cell Death and Differentiation (2008) 15, 354-363; doi:10.1038/sj.cdd.4402264; published online 23 November 2007

Apoptosis of T lymphocytes is a physiological mechanism by which an efficient immune system prevents autoimmunity and ensures T-cell homeostasis. ${ }^{1}$ The regulation of $\mathrm{Bcl}-2$ family proteins represents a critical checkpoint in the apoptotic pathway and is important to determine the cell fate in the lymphoid system. The Bcl-2 family comprises multidomain proteins with antiapoptotic (Bcl-2, Bcl-xL, Bcl-W, 1, A1Bfl-1) and proapoptotic functions (Bax, Bak, Bid, Bim, Hrk), and a subset of proapoptotic members known as $\mathrm{BH}$-only proteins with regulatory functions. The $\mathrm{BH}$-only proteins (i.e., Bid, Bad, Bim, Noxa, Puma) communicate both extrinsic (death receptor, growth factor, T-cell receptor (TCR)) and intrinsic death stimuli (DNA damage) to Bax and Bak favoring their oligomerization, the release of cytochrome $c$ from the mitochondrial membrane and subsequently inducing cell death. The balance between proapoptotic (Bax, Bak) and antiapoptotic members (Bcl-2, Bcl-xL) determines how the cell will respond to an apoptotic signal. ${ }^{2,3}$ Indeed, antiapoptotic members of the Bcl-2 family may sequester the proapoptotic proteins, thus preventing mitochondrial damage and apoptosis. ${ }^{4}$ In summary, the downregulation of antiapoptotic and the induction of proapoptotic members of the Bcl-2 family, such as Bax, are required to activate the cell death programs.

The transcription factor NF- $\kappa \mathrm{B}$ can be considered a major regulator of lymphocyte survival. In mammals, this family consists of five members that form homo- and heterodimeric complexes, including NF- $\kappa \mathrm{B} 1$ (p50 and its precursor p105),
NF- $\kappa$ B2 (p52 and its precursor p100), RelA (p65), RelB and c-Rel. RelA, RelB and c-Rel contain trans-activating domains (TADs) and are able to activate transcription. p50 and p52 lack $\mathrm{a} T A D$ and therefore may form transcriptionally active heterodimers in association with RelA, RelB and c-Rel. ${ }^{5} \mathrm{NF}-\kappa \mathrm{B}$ activity is regulated by inhibitory proteins belonging to the $I_{\kappa} B$ family (which include $\mathrm{I}_{\kappa} \mathrm{B} \alpha, \mathrm{I}_{\kappa} \mathrm{B} \beta$ and $\mathrm{I} \kappa \mathrm{B} \varepsilon$ ), with the function to retain $\mathrm{NF}-\kappa \mathrm{B}$ dimers in the cytoplasm. A protein kinase complex, known as IKK signalsome, phosphorylates $I_{\kappa} \mathrm{B} \alpha$, $\mathrm{I}_{\kappa} \mathrm{B} \beta$ and $\mathrm{I}_{\kappa} \mathrm{B} \varepsilon$, inducing their proteolytic degradation and the subsequent translocation of NF- $\kappa \mathrm{B}$ into the nucleus. ${ }^{6}$

$\mathrm{NF}-\kappa \mathrm{B}$ activation can suppress cell death pathways through the transcriptional activation of the $\mathrm{Bcl}-2$ homologues $\mathrm{A} 1 / \mathrm{Bfl}-1$ and $\mathrm{Bcl}-\mathrm{xL}$. Recently, NF- $\kappa \mathrm{B}$ has been also involved in the downregulation of Bax expression, in some human cancers (colon, breast and ovarian cancer cell lines) ${ }^{7}$ and in EpsteinBarr virus-infected B cells. ${ }^{8}$ Transcription of the bax gene is controlled by several transcription factors, including the tumor suppressor proteins belonging to p53 family. ${ }^{9}$ Bax promoter contains a DNA consensus sequence for binding of the tumor suppressor protein p53. Exogenously expressed p53 increases bax expression in several cell types, and this increase correlates with the induction of apoptosis. ${ }^{10}$ In some cell lines, p53 binds the bax gene promoter weakly when compared with other target promoters (i.e., puma), suggesting that bax may not represent the major target gene for p53. ${ }^{11}$ Recently, another member of the $\mathrm{p} 53$ family, p73, with trans-activating

\footnotetext{
${ }^{1}$ Department of Cellular and Developmental Biology, University 'La Sapienza', Via dei Sardi 70, 00185 Rome, Italy; ${ }^{2}$ Department of Dermatology, University 'Tor Vergata', Viale Oxford 81, 00133 Rome, Italy; ${ }^{3}$ Fondazione Andrea Cesalpino, Policlinico Umberto I, University 'La Sapienza', 00185 Rome, Italy and ${ }^{4}$ Rome Oncogenomic Center, 00100 Rome, Italy

*Corresponding authors: L Tuosto, Department of Cellular and Developmental Biology, University 'La Sapienza', Via dei Sardi 70, 00185 Rome, Italy.

Tel: + 3906 49917595; Fax: + 3906 49917594; E-mail: loretta.tuosto@uniroma1.it or A Costanzo, antonio.costanzo@uniroma2.it Keywords: NF- $\kappa$ B; p73; apoptosis; costimulation; memory T cells

Abbreviations: AICD, activation-induced cell death; CBP, CAMP-responsive element-binding protein-binding protein; ChIP, chromatin immunoprecipitation; HDAC, histone deacetylase; IR, ionizing radiation; PBMC, peripheral blood mononuclear cell; pol II, RNA polymerase II; TA, trans-activating; TAD, trans-activating domain; TCR, T-cell receptor; YAP, Yes-associated protein

Received 11.1.07; revised 20.8.07; accepted 26.9.07; Edited by G Melino; published online 23.11.07
} 
potential on the bax gene promoter has been identified. p73 is expressed in multiple isoforms (p73 $\alpha-\zeta)$, derived from alternative splicing at the $3^{\prime} .^{12,13}$ Interestingly, whereas p53 serves as a checkpoint protein for DNA damage, p73 integrates stimuli for both DNA damage and receptormediated apoptosis in T cells. ${ }^{14}$ A connection between p73 and the NF- $\kappa$ B pathway has been recently proposed in $T$ lymphocytes, where costimulation-induced NF- $\kappa \mathrm{B}$ activity has been related to the inhibition of $p 73$ expression. ${ }^{15}$ Thus, an interplay between NF- $\kappa \mathrm{B}$ and $\mathrm{p} 73$ exists that may play an important role in regulating the fate of $\mathrm{T}$ lymphocytes.

Here, we report that CD28 engagement by B7 protects memory $T$ cells from irradiation-induced apoptosis, by modulating the expression of both anti- and proapoptotic proteins of the Bcl-2 family. We found that in irradiated T cells p73, but not p53, binds to and trans-activates the bax gene promoter and that CD28 costimulation inhibits p73-induced bax transcription. The RelA/NF- $\kappa$ B subunit in CD28-costimulated $\mathrm{T}$ cells suppresses bax gene transcription by a direct binding to the bax gene promoter and interferes with the recruitment of both p73 and RNA polymerase II (pol II). Data obtained by using specific inhibitors evidenced the involvement of PI3K/Akt pathway in CD28-mediated inhibition of both Bax expression and apoptosis. These findings reveal a new mechanism by which NF- $\kappa \mathrm{B}$ can promote T-cell survival.

\section{Results}

CD28 costimulation protects $T$ cells from radiationinduced apoptosis by regulating both $b c /-x L$ and bax transcriptional activation. We have recently demonstrated that CD28 ligation by B7 in the absence of TCR stimulation protects memory $T$ cells from ionizing radiation (IR)-induced apoptosis and induces the recruitment of RelA on the $b c l-x L$ gene promoter, thus upregulating $\mathrm{Bcl}-\mathrm{xL}$ expression ${ }^{16}$ (Supplementary Figure 1). Starting from these data, we analyzed the effects of CD28-mediated survival signals on the expression of proapoptotic genes. In particular, we looked at the transcription of bim, puma and bax genes, being the major mediators of mitochondria-dependent apoptosis. Bax gene transcription was induced as early as $2 \mathrm{~h}$ post irradiation and started to decrease after $8 \mathrm{~h}$ (Figure 1a). By contrast, bim and puma expressions, which were efficiently upregulated in PMA-treated human memory $T$ cells, were not induced following IR treatment (Figure 1a, middle panels). CD28 stimulation strongly inhibited bax (Figure 1a, lanes 4 and 5 versus 2 and 3). Consistently with our recent data, ${ }^{16} \mathrm{bcl}-x \mathrm{~L}$ gene expression was induced $8 \mathrm{~h}$ after CD28 engagement (Figure 1a, upper panel, lane 5). Bax gene transcription was also accompanied by a strong increase of Bax protein levels, which were significantly reduced following CD28 stimulation (Figure 1b, upper panel). We also analyzed the expression of both p53 and p73 proteins, being involved in the regulation of proapoptotic gene expression during IR-induced apoptosis. ${ }^{17,18}$ We found that primary $\mathrm{T}$ cells expressed basal protein levels of $\mathrm{p73}$, which did not change following irradiation (Figure 1b, middle panel). On the basis of its molecular weight $(\sim 80 \mathrm{kDa})$ and co-migration with exogenously expressed HA-p73 $\alpha$
(Supplementary Figure 3, lower panel), the p73 isoform found in $T$ cells is likely $p 73 \alpha$. Although no significant changes in p73 protein levels were observed in IR-treated $T$ cells, data obtained from radioactive RT-PCR evidenced an early ( $2 \mathrm{~h}$ after IR) and transient induction of $p 73 \alpha$ transcription that was completely inhibited following CD28 stimulation (Figure 1c, upper panel). By contrast, p53 levels were strongly induced after IR and were not affected by CD28 (Figure 1b, middle panel). No change in RelA content was observed in IR-treated cells (Figure 1b, lower panel).

The analysis of bax gene promoter occupancy by chromatin immunoprecipitation (ChIP) experiments revealed that p73 was recruited on the promoter in the early phase of IR-induced transcriptional activation (Figure 1d, upper panel, lanes 1-3). By contrast, endogenous p53 did not bind the bax gene promoter in irradiated $\mathrm{T}$ cells (Figure $1 \mathrm{~d}$, middle panel), although it was recruited on to the $\triangle N p 73$ promoter and efficiently trans-activated it (Figure $3 c$ and d). The induction of $\Delta N p 73$ expression by $p 53$ has been described to create dominant-negative feedback loop that fine tunes the function of p53. ${ }^{19}$ The relevance of p73 in IR-induced apoptosis was evidenced by the silencing with oligonucleotide small interfering RNA (siRNA) duplexes, which specifically downregulate the expression of several p73 isoforms (Figure 2b). As shown in Figure $2 \mathrm{a}$, the inhibition of p73 expression was associated with a significant reduction (around 40\%) of IR-induced apoptosis (Figure 2a). By contrast, the downregulation of p53 (Supplementary Figure $2 b$ ) obtained by transfecting cells with two p53 siRNA duplexes did not affect IR-induced apoptosis (Supplementary Figure $2 b$ ). Similarly to p73, silencing of bax transcript significantly protects cells from IR-induced apoptosis (Supplementary Figure 2c and d). Unrelated siRNA (ctr) did not exert any significant effect.

CD28 stimulation significantly inhibited p73 and RNA pol II recruitment on the bax gene promoter (Figure 2c, upper and middle panels, lanes 4 and 5 versus 2 and 3 ). The loss of both p73 and RNA pol II bindings correlated with the recruitment of RelA on the bax gene promoter in CD28-stimulated cells (Figure 2d, upper panels). Consistently with our previous data, ${ }^{16}$ RelA was recruited on and trans-activated the $b c l-x L$ gene promoter (Figure 2d, middle panel, lanes 4 and 5). Altogether these data indicate that the in vivo recruitment of RelA/NF- $\kappa$ B on the bax gene promoter in CD28-costimulated $\mathrm{T}$ lymphocytes is paralleled by a decrease in IR-induced p73 recruitment and transcriptional activity.

The bax gene promoter is trans-activated by $\mathrm{p} 73$, but not p53, in Jurkat cells. To further define the role of p73 in the trans-activation of the bax gene promoter, we used a Jurkat $T$ cell line that expresses endogenous $p 73$, but not detectable p53, undergoes apoptosis and upregulates Bax after IR (data not shown). Jurkat cells were transfected with a bax-luciferase reporter construct, containing the luciferase gene under the control of the bax promoter $(-715$ to $-317 \mathrm{bp})$, in the presence of either HA-tagged p73 $(\alpha-\delta)$ or Flag-p53 expression vectors. All the p73 isoforms were able to trans-activate the bax promoter, although to different degrees (Figure $3 a$ ), with $p 73 \alpha$ and $p 73 \gamma$ being the most potent trans-activators. By contrast, p53 did not significantly upregulated bax expression under the same experimental 
a

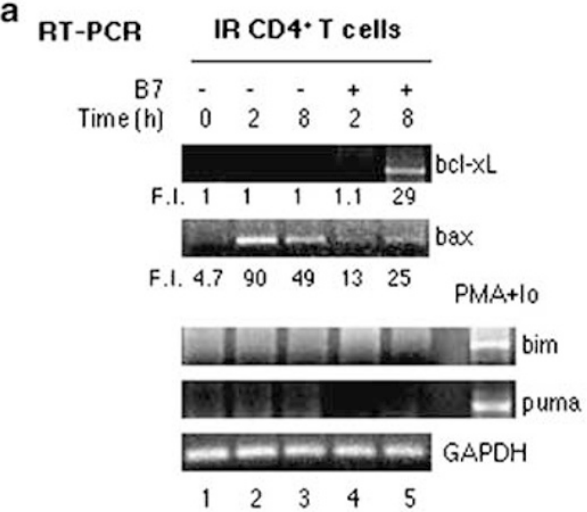

C
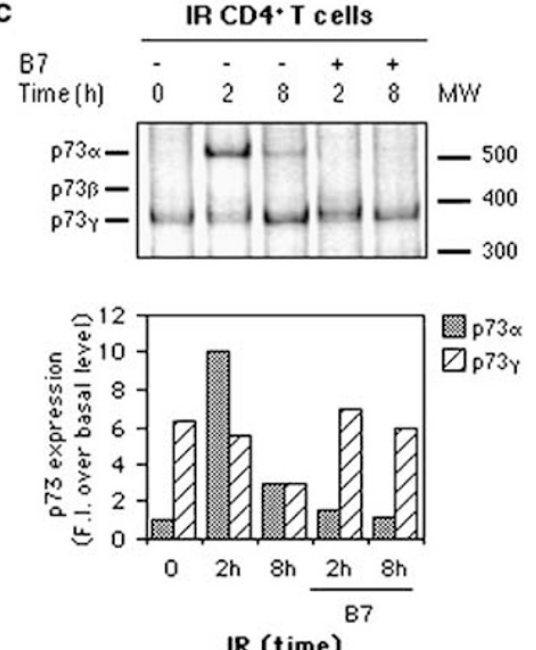

b WB CD4. T cells

IR -++

B7 : - +

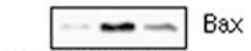

F.I. 1410258

- - $\mathrm{p} 73$

F.I. 130139110
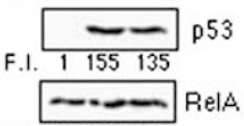

F.I. 245262283

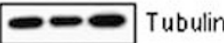

d

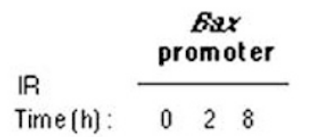

Chip $\longrightarrow$ p73

F.I. $\begin{array}{lll}1.2 & 21 & 12\end{array}$

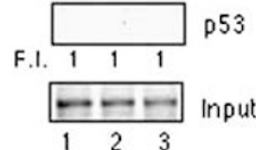

Figure 1 CD28 interferes with IR-induced apoptosis by both inducing $b c l-x L$ and inhibiting bax gene expressions. Human CD4 ${ }^{+} \mathrm{T}$ cells were exposed to 5 Gy of $\mathrm{X}$-ray radiation and cultured in the presence (B7) for different times. (a) RT-PCR analysis of bcl-xL, bax, bim, puma and GAPDH of irradiated T cells. (b) Post-irradiation (24 h) Bax, p73, p53, RelA and tubulin protein expressions were analyzed by western blotting. Protein content was quantitated and expressed as fold induction (FI) over the basal level. (c) Radioactive RT-PCR for p73 and GAPDH performed on mRNA extracted from irradiated T cells. The position of p73 splice variants (p73 $\alpha: 535 \mathrm{bp} ; \mathrm{p} 73 \beta$ : $440 \mathrm{bp}$ and p73 $\gamma$ : $386 \mathrm{bp}$ ) and molecular weight (MW) are shown. Radioactive PCR gel for p73 was exposed for $10 \mathrm{~h}$. Data (a, c) were quantified and expressed as fold induction (FI) over the basal level. (d) Anti-p73 and p53 ChIPs were analyzed by PCR with bax promoter-specific primers. Data were quantified and expressed as fold induction (FI) over the basal level

conditions, although it was able to bind and trans-activate the $\Delta$ Np73 promoter both in vitro (Figure $3 c$ ) and in IR T cells (Figure $3 d$ ). Similar results were obtained in another $T$ cell line (Hut-78), thus indicating that in $T$ cells p53 does not regulate bax transcription as observed in other cancer cell lines $^{10}$ (data not shown).

The bax gene promoter contains four potential p53-binding sites. These binding sites reside within a 39-bp region $(-486$ to $-448 \mathrm{bp}$ ) that has been identified as sufficient for p53mediated trans-activation ${ }^{10}$ and to bind exogenous HA-p73 $\alpha$ in EMSA assays (data not shown). Consistently with the high homology shared by p53 and p73 in their DNA-binding domain as well as in their ability to activate largely overlapping sets of genes, ${ }^{9}$ p73-induced bax transcription depended on the presence of its TAD, as demonstrated by the inability of a p73 $\alpha$ mutant $(\Delta 85 p 73 \alpha)$, lacking the TAD, to significantly upregulate bax-luciferase activity (Figure 4a). Furthermore, p73 $\alpha$ was not able to trans-activate the mutp53 bax-luciferase vector (Figure 4c), containing three nucleotide substitutions within one of the consensus p53-binding sites ( -474 to $-465 \mathrm{bp}) .{ }^{10}$
Similarly to primary T cells, exogenously expressed p73 was recruited on endogenous bax gene promoter concomitantly with the RNA pol II, thus evidencing its role in bax transcriptional activation (Figure $4 \mathrm{~d}$, left panels). No binding of transfected p73 on endogenous puma gene promoter was observed (Figure 4d, right panel), thus indicating that p73 specifically induces bax transcription by directly binding the bax promoter in the p53-binding sites.

RelA/NF- $\kappa$ B subunit antagonizes p73-induced bax transcription and inhibits both p73 and RNA pol II recruitment onto the bax gene promoter. We next tested different NF- $\kappa$ B subunits for their ability to inhibit p73-induced bax transcription. Jurkat cells were transfected with baxluciferase construct together with $p 73 \alpha$ in the presence or absence of individual HA-tagged RelA, RelB plasmids or expression vectors encoding for $\mathrm{p} 50$ or p52. RelA/p65 strongly interfered with p73-mediated bax transcription when overexpressed in Jurkat cells (Figure 5a), whereas the other NF- $\kappa \mathrm{B}$ subunits did not exert any significant effects 
a
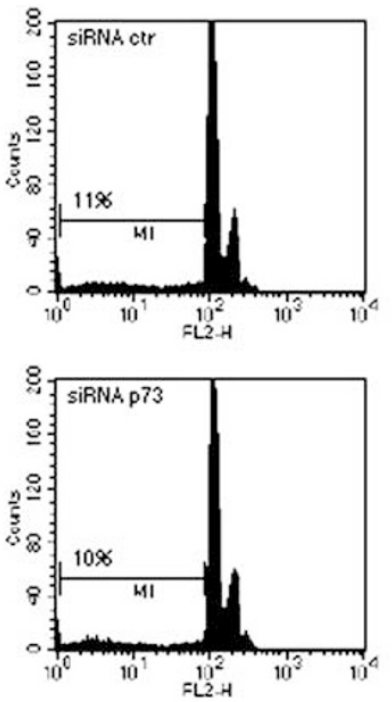
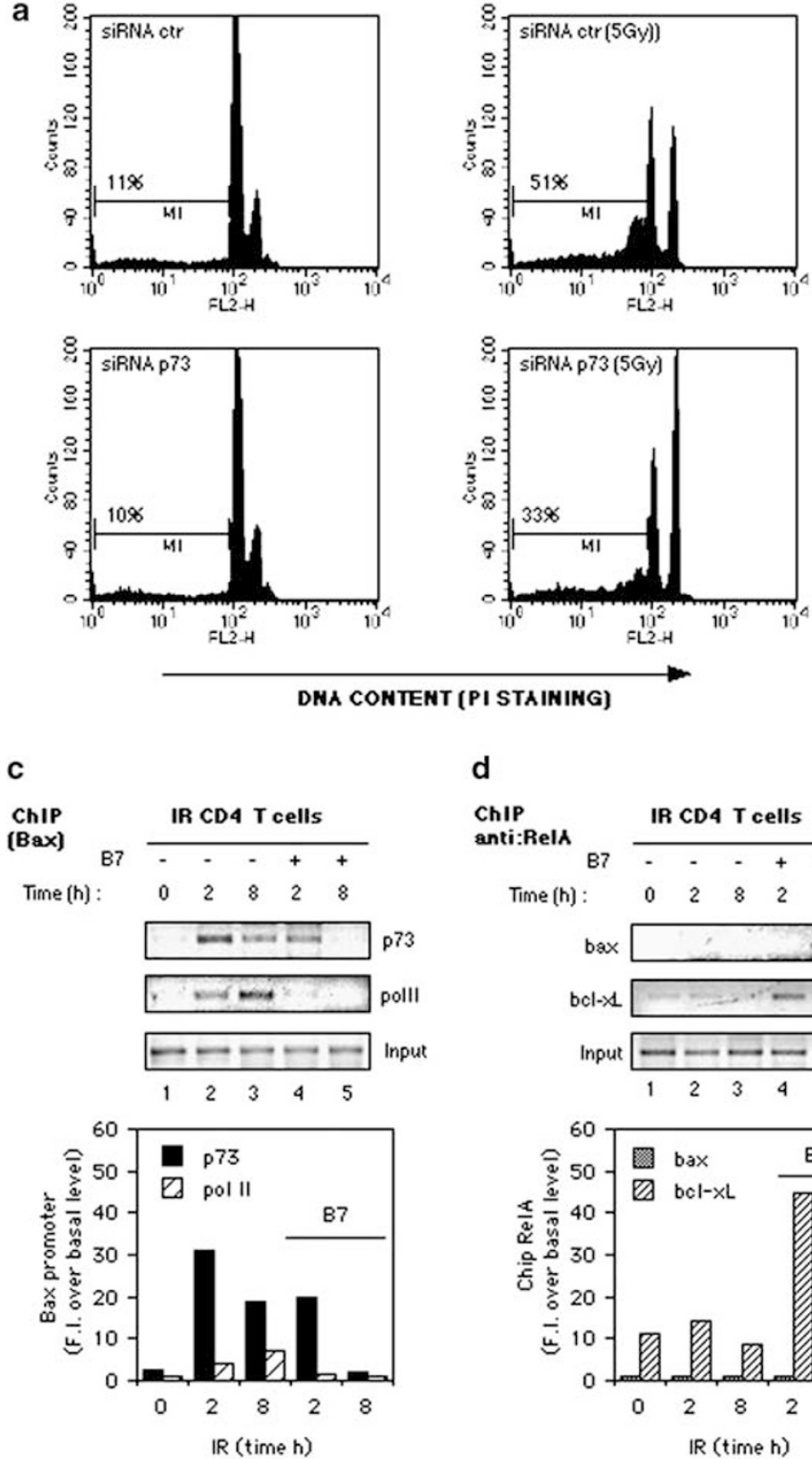

d anti:RelA Time (h)
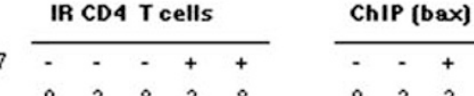

bax

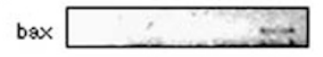

bcl- $>1$ W

Input $\longrightarrow-\longrightarrow$
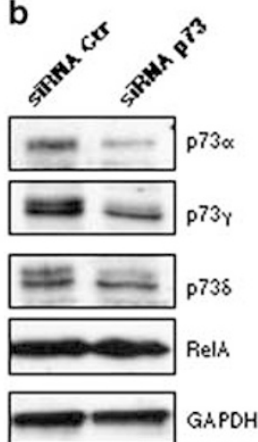

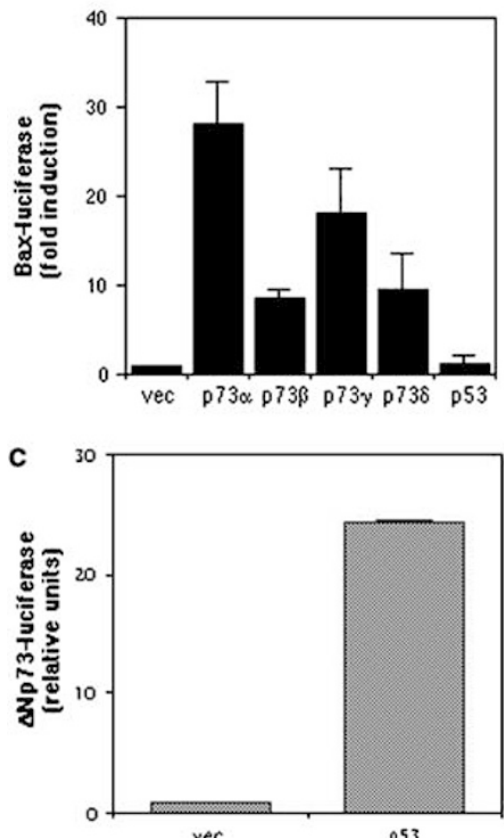

b
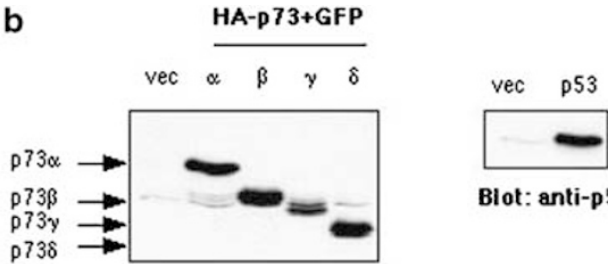

Blot: anti-p53
Blot: anti-HA

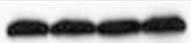

Blot: anti-GFP

d

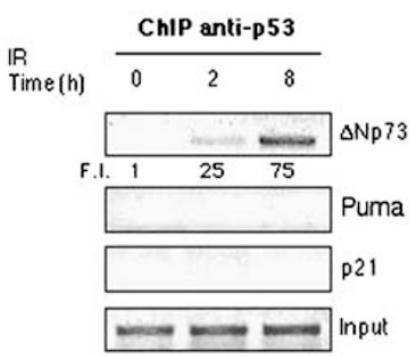

Figure $3 \mathrm{p} 73$, but not p53, induces the transcriptional activation of bax gene in Jurkat cells. Jurkat cells were transfected with $10 \mu \mathrm{g}$ bax-luciferase reporter construct together with empty vector (vec) or $10 \mu \mathrm{g} \mathrm{HA}$-tagged $\mathrm{p} 73(\alpha-\delta)$ or $10 \mu \mathrm{g}$ Flag-tagged p53 expression vectors. After $8 \mathrm{~h}$, luciferase activity (a) and anti-HA (b, upper panel), anti-p53 (b, lower panel) and anti-GFP western blotting were analyzed. (a) The results are expressed as fold induction over the basal activity after normalization to GFP values. The results express the mean \pm S.D. of three different experiments. (c) Jurkat cells were transfected with $10 \mu \mathrm{g} \Delta \mathrm{Np}$-73-luciferase reporter construct together with empty vector (vec) or $10 \mu \mathrm{g}$ Flag-tagged p53. After $8 \mathrm{~h}$, luciferase activity was analyzed. The results were expressed as the mean of arbitrary luciferase units \pm S.D. after normalization to GFP values. (d) Human $\mathrm{Cd} 4^{+} \mathrm{T}$ cells were exposed to $5 \mathrm{~Gy}$ X-ray for different times. Anti-p53 ChIPs were analyzed by PCR with $\triangle \mathrm{Np} 73$, or puma or p21 promoter-specific primers. Data were quantified and expressed as fold induction $(\mathrm{FI})$ over the basal level

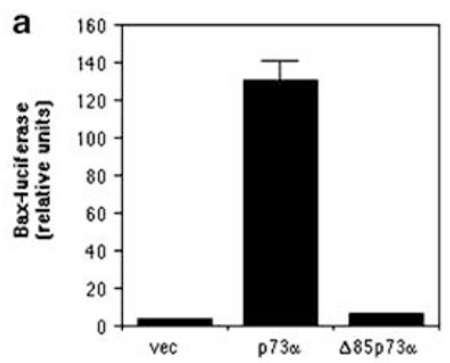

b

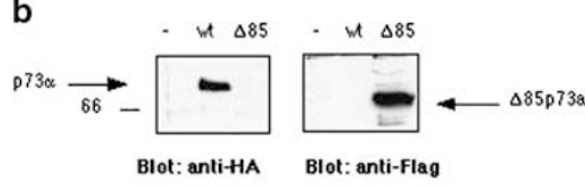

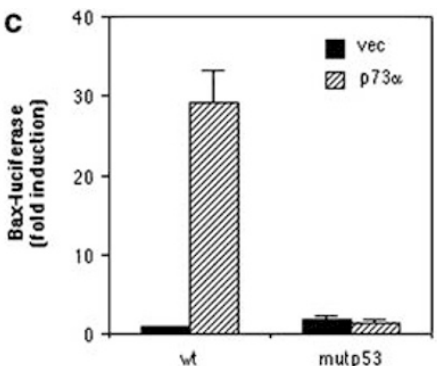

d

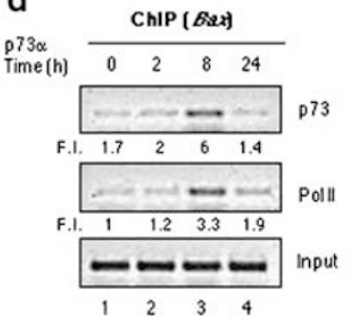

ChIP ( $P$ oms $)$
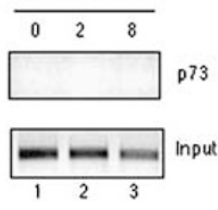

Figure 4 p73 binds the bax gene promoter and activates its transcription. (a) Luciferase activity of Jurkat cells transfected for $8 \mathrm{~h}$ with bax-luciferase reporter construct together with empty vector or HA-tagged $\mathrm{p} 73 \alpha$ or Flag-tagged $\triangle 85 \mathrm{p} 73 \alpha$, deleted of the TAD. The results are expressed as the mean of arbitrary luciferase units \pm S.D. after normalization to GFP values. The data represent at least four independent experiments. (b) An aliquot of each sample was analyzed by immunoblotting with anti-HA Ab for p73 $\alpha$ content or anti-Flag Ab for $\Delta 85 p 73 \alpha$ content. (c) Jurkat cells were transfected for $8 \mathrm{~h}$ with bax-luciferase construct (wt) or bax-luciferase deleted of the p53-binding region (mutp53) together with empty vector (vec) or HA-p73 $\alpha$ vector. The results are expressed as fold induction over the basal activity after normalization to GFP values. The results express the mean \pm S.D. of three different experiments. (d) Jurkat cells were transfected with HA-p $73 \alpha$ expression vector, and ChIPs were performed using anti-p73 or antiRNA pol II antibodies after different times (0-24 h). Immunoprecipitated DNA was analyzed by PCR with either bax (left panel) or puma (right panel) promoter-specific primers, quantified and expressed as fold induction (Fl) over the basal level. Data are representative of five independent experiments 
a
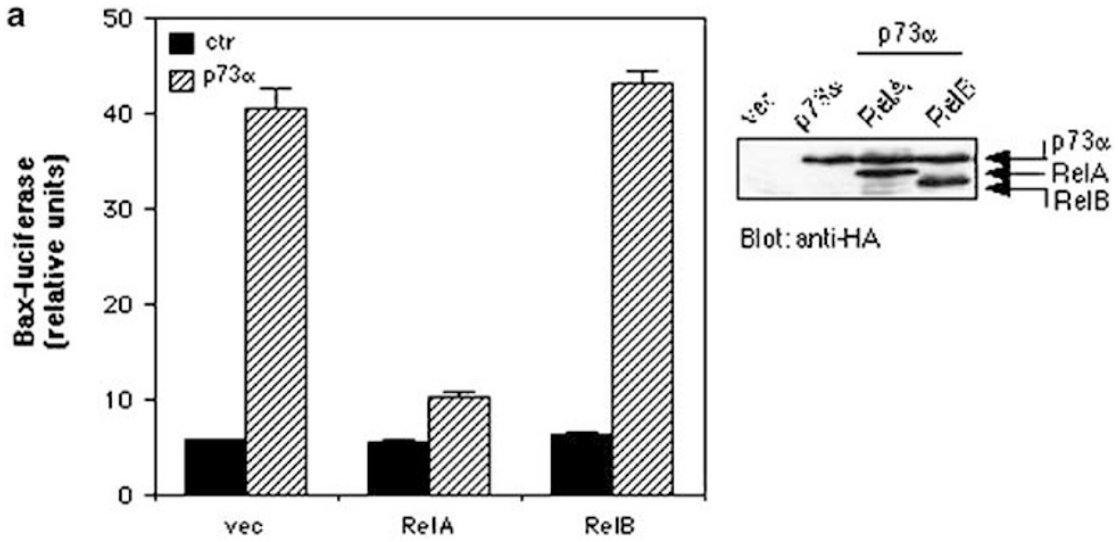

Blot: anti-HA
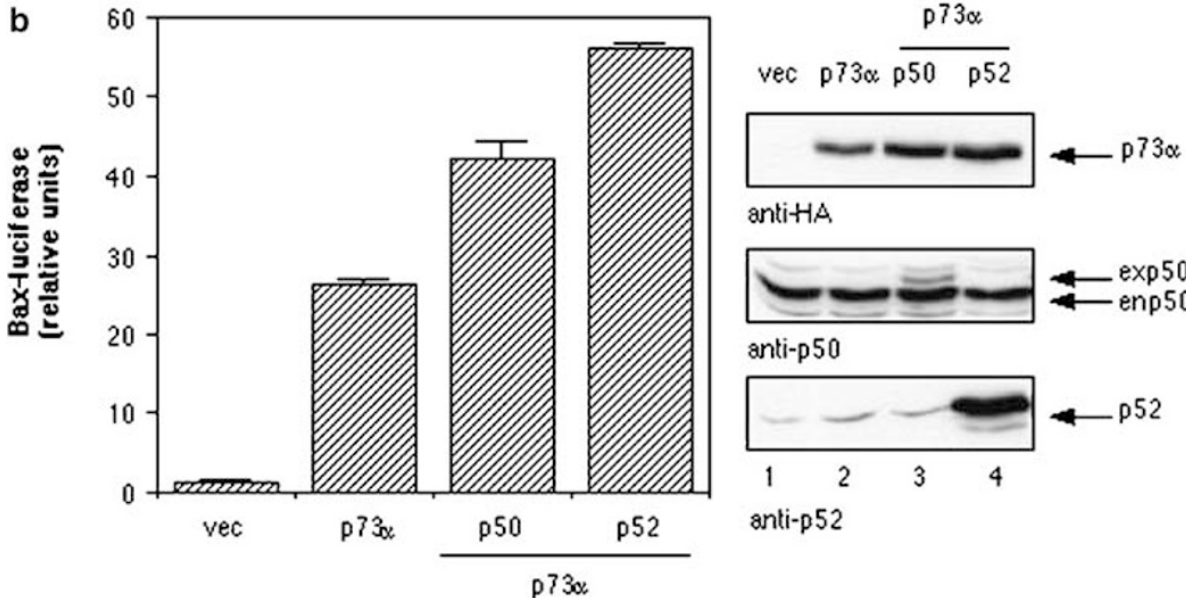

anti+HA

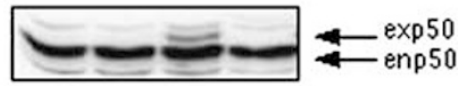

anti-p50

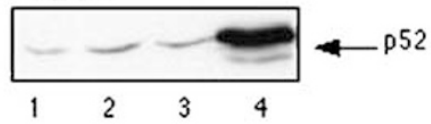

anti-p52

Figure 5 RelA/NF- $\kappa$ B inhibits p73-induced transcriptional activation of bax gene. Luciferase activity of Jurkat cells transfected for $8 \mathrm{~h}$ with bax-luciferase construct together with empty vector (vec), or HA-p73 $\alpha$ or HA-p73 $\alpha$ plus $10 \mu \mathrm{g} \mathrm{HA}-$ RelA, or HA-RelB (a) or p50 or p52 (b) expression vectors. The results are expressed as the mean of arbitrary luciferase units \pm S.D. after normalization to GFP values. An aliquot of each sample was analyzed by immunoblotting with anti-HA Ab for p $73 \alpha$, RelA and RelB contents, antip50 or anti-p52 Abs. The data represent at least four independent experiments

gel shift (EMSA) assays (data not shown), suggested that the inhibition of p73-mediated transcriptional activation of the bax gene promoter could rely in part on the binding of RelA to the bax promoter. To further verify this hypothesis, Jurkat cells were transfected with $\mathrm{p} 73 \alpha$ or RelA expression vectors alone or in combination, and anti-p73 or anti-RelA ChIP assays were performed on the endogenous bax gene promoter. RelA was recruited to the endogenous bax promoter $8 \mathrm{~h}$ after transfection (Figure 6c, left upper panel, lane 2), and no significant changes in its binding level were observed following the coexpression of p73 (Figure 6c, left upper panel, lane 3). By contrast, the recruitment of both p73 and RNA pol II was inhibited in the presence of RelA (Figure 6c, right upper and middle panels, lanes 3 versus 2).

Altogether these results indicate that exogenously expressed RelA/NF- $\kappa$ B subunit antagonizes p73-induced bax transcription by inhibiting $\mathrm{p} 73$ recruitment onto the bax gene promoter but do not clarify the mechanisms of RelAmediated repression of bax expression in response to CD28 costimulation. One mechanism may involve the sequestration of key p73 coactivators such as the p300/cAMP-responsive element-binding protein-binding protein (CBP) and/or the recruitment of corepressors histone deacetylase (HDAC) on the bax promoter, as previously demonstrated in other systems. $^{20,21}$ As shown in Figure 6d, CD28 triggering interfered with the recruitment of p73/p300 complexes to the bax gene promoter and promoted the binding of HDAC-1containing complexes. Moreover, pretreatment of $T$ cells with the HDAC-1 inhibitor trichostatin A (TSA), strongly inhibited the survival signals mediated by CD28 and restored IR-induced Bax expression (Supplementary Figure 2).

The Akt pathway interferes with p73-mediated transcription of bax gene by inducing RelA recruitment to the bax promoter. The protein kinase B, Akt, has been recently discovered as a critical mediator of survival in $T$ cells, acting specifically downstream of CD28 through the activation of NF- $\kappa B^{22,23}$ The involvement of Akt and NF- $\kappa$ B in CD28 survival signals was supported by the observation that the inhibitor of PI3K/Akt pathway, LY294002, as well as MG101, a proteasome inhibitor that blocks RelA nuclear translocation and transcriptional activity, without affecting RelA expression (Supplementary Figure $2 b$, middle panel), restored both IR-induced apoptosis and Bax protein levels in CD28-costimulated T cells, without affecting p53 levels. Finally, Akt overexpression in Jurkat cells completely 


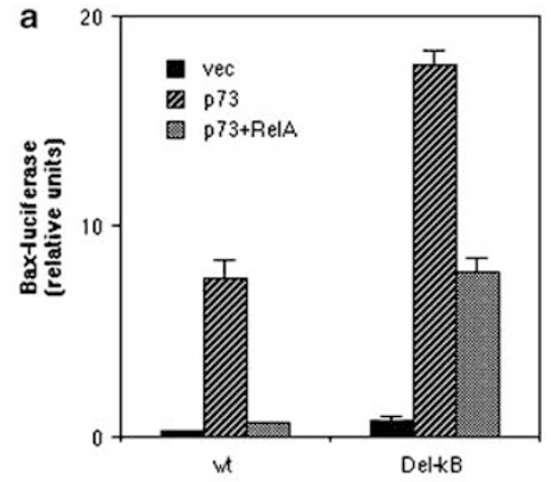

C

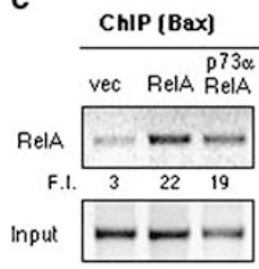

b

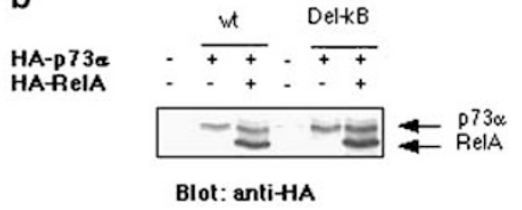

d

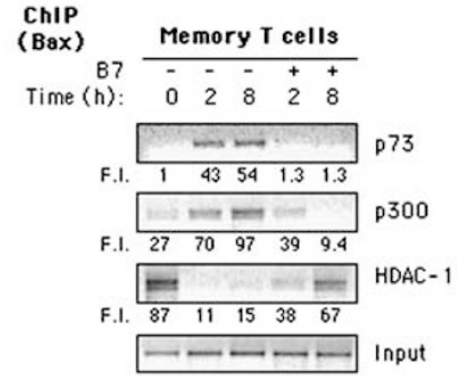

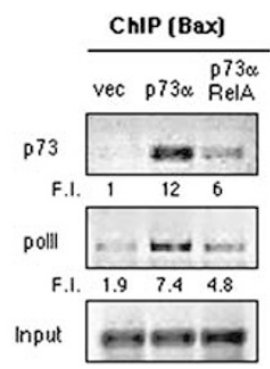

Figure 6 RelA recruitment to the bax gene promoter inhibits both p73 binding and transcriptional activity. (a) Luciferase activity of Jurkat cells transfected with wt baxluciferase or bax-luciferase construct deleted of the putative NF- $\kappa$ B binding region (Del- $\kappa$ B) together with $p 73 \alpha$ or $p 73 \alpha$ and RelA constructs. The results are expressed as the mean of arbitrary luciferase units \pm S.D. after normalization to GFP values. Data are representative of at least three independent experiments. (b) Each sample was analyzed by immunoblotting with anti-HA Abs. (c) Anti-RelA, or anti-p73 or anti-RNA pol II ChIP assays were performed on Jurkat cells transfected for $8 \mathrm{~h}$ with HA-p73 $\alpha$ or HA-RelA expression vectors alone or in combination. Immunoprecipitated DNA was analyzed by PCR with bax promoter-specific primers. The data represent at least three independent experiments. (d) Human memory CD4 ${ }^{+} \mathrm{T}$ cells were exposed to $5 \mathrm{~Gy} \mathrm{X}$-ray radiation and cultured in the presence (B7) or absence (ctr) of adherent Dap/B7 cells for different times. Anti-p73, anti-p300 or anti-HDAC-1 ChIPs were analyzed by PCR with bax promoter-specific primers. (c, d) Data were quantified and expressed as fold induction (FI) over the basal level

inhibited both p73 binding (Figure 7b, upper panel, lanes 4 versus 3 ) and trans-activation of the bax gene (Figure 7a), by inducing RelA recruitment to the bax promoter (Figure 7b, middle panel, lanes 4 versus 2). A hypothetical model is reported in Figure $7 \mathrm{c}$.

\section{Discussion}

It is well established that members of the Bcl-2 protein family are cardinal regulators of $\mathrm{T}$-cell viability and the ratio of antiapoptotic (Bcl-2, Bcl-xL) to proapoptotic (Bax, Bak) members may be considered a rheostat that determines susceptibility to cell death. Bcl-2 protein activities are regulated by both transcriptional and post-translational mechanisms. However, the mechanisms and the transcription factors that regulate $\mathrm{Bcl}-2$ family members at the promoter level are not completely known, as well as the effects of CD28 costimulation on the expression of other Bcl-2 family members. In this article, we present evidence that CD28 engagement by $\mathrm{B} 7$ delivers survival signal in memory $\mathrm{T}$ cells by both upregulating $b c l-x L$ and inhibiting p73-mediated bax gene transcription in a RelA/NF- $\kappa$ B-dependent manner.

In T cells, Bax is one of the major proapoptotic agents. Bax deficiency alters both thymic selection and lymphoid homeostasis. ${ }^{24}$ The presence of four motifs with homology to consensus p53-binding site in the bax gene promoter and the ability of p53 to trans-activate bax gene when overexpressed in some cancer cell lines, identified bax as a p53 target gene. ${ }^{10}$ The use of quantitative ChIP assays has recently revealed that the bax gene promoter binds p53 very weakly, when compared to other p53 target genes, such as noxa and puma, ${ }^{11}$ which have been described as critical mediators of the apoptotic responses induced by $p 53 .{ }^{25}$ Consistently, we found that p53 was not recruited to the bax promoter in irradiated T cells (Figure 1d), although it was able to transactivates bax gene when overexpressed in Cos7 cells or in A2780 ovarian cancer cells (data not shown). Thus, our data indicate that in human T cells $\mathrm{p} 73$ is the major regulator of bax gene transcription and is involved in IR-induced apoptosis, as demonstrated by the use of specific siRNA to inhibit p73 expression (Figure 2a). These data seem apparently in contrast with those obtained from both p53- and p63/p73deficient mice. ${ }^{26,27}$ However, in both systems apoptosis was analyzed only in IR-treated thymocyte ${ }^{26,27}$ or in mature T cells following TCR restimulation. ${ }^{26,27}$ No data on the susceptibility to IR-induced apoptosis of mature T cells have been shown.

We also show that p73 functions are counteracted by RelA/NF- $\kappa \mathrm{B}$, thus reinforcing the current notions of a cross talk between these two transcription factors in regulating T-cell survival. RelA/NF- $\kappa$ B acts as a key prosurvival factor by regulating the expression of antiapoptotic genes of the $\mathrm{Bcl}-2$ family, in particular $A 1 / B f l-1$ and $b c l-x L$. However, Bcl-xL upregulation promotes $\mathrm{T}$-cell survival ${ }^{28}$ but does not protect T cells from activation-induced cell death (AICD). ${ }^{29,30}$ TCRAICD has been recently described to depend on both E2F-1 and $\mathrm{p} 73^{14}$ and NF- $\kappa$ B may counteract TCR-driven apoptosis 
a

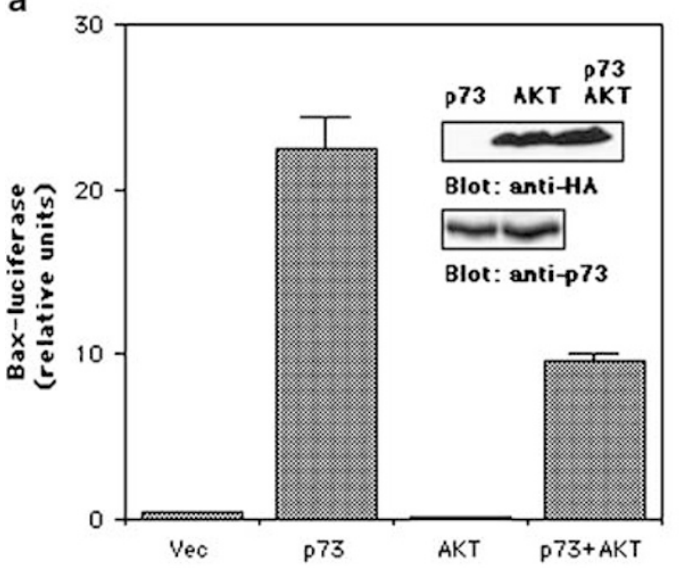

ChIP [ fext

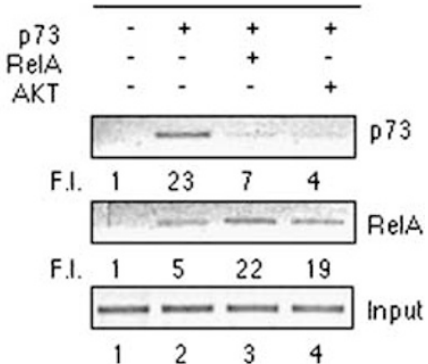

C

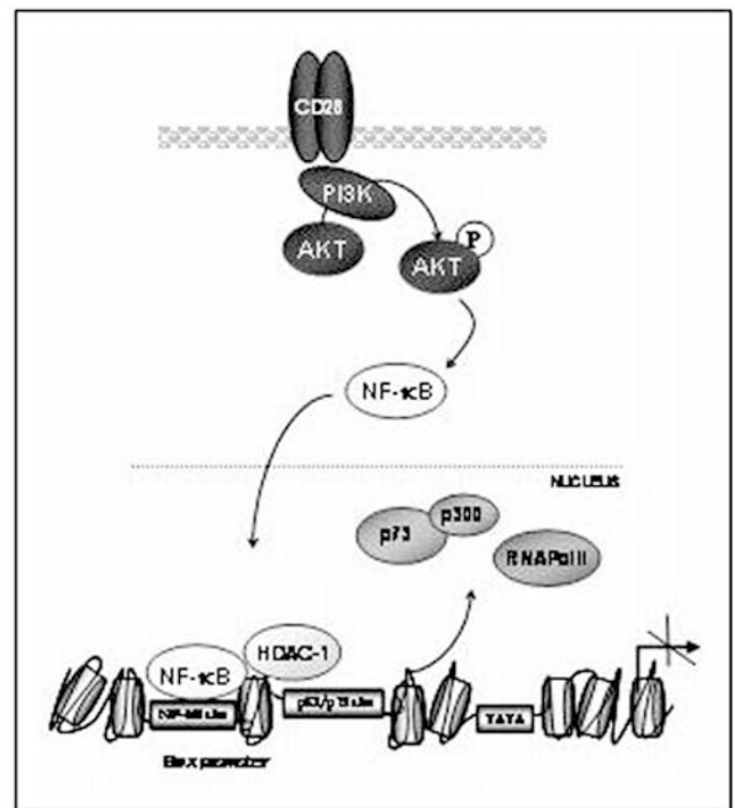

Figure 7 Akt induces RelA recruitment to the bax gene promoter and inhibits both $\mathrm{p} 73$ binding and trans-activation of the bax gene. (a) Bax-luciferase activity of Jurkat cells transfected with empty vector (vec) $p 73 \alpha$ or p $73 \alpha$ and Akt constructs. The results are expressed as the mean of arbitrary luciferase units \pm S.D. after normalization to GFP values. Each sample was analyzed by immunoblotting with anti-p73 or anti-HA Abs (insert panel). (b) Jurkat cells were transfected with empty vector (-) or p73 $\alpha$ or p $73 \alpha$ plus RelA or plus Akt for $8 \mathrm{~h}$. Anti-p73 or anti-RelA ChIPs were analyzed by PCR with bax promoter-specific primers. Data were quantified and expressed as fold of induction (FI) over the basal level. The data represent at least three independent experiments. (c) Schematic model of the CD28 signaling pathway leading to the recruitment of NF- $k \mathrm{~B} /$ HDAC-1 complexes on the bax gene promoter and to the inhibition of both p73/p300 and RNA pol II binding. The positions of NF- $k B$ and p53 binding regions as well as TATA box are indicated

by inhibiting p73 expression. ${ }^{15}$ Our data on the ability of RelA to bind the bax gene promoter and to interfere with p73induced bax transcription evidence a novel mechanism by which NF- $\kappa \mathrm{B}$ may regulate T-cell survival. Indeed, RelAmediated inhibition of p73-induced bax gene expression is accompanied by the recruitment of RelA to the bax gene promoter and the parallel inhibition of p73 binding (Figure 2). Moreover, the deletion of three potential NF- $\kappa \mathrm{B}$ binding sites from the bax gene promoter, ${ }^{7}$ restores significantly, but not completely, p73-mediated transcriptional activation (Figure 6a). The putative binding sites for NF- $\kappa \mathrm{B}$ and $\mathrm{p} 53 / \mathrm{p} 73$ within the bax promoter are very close. ${ }^{7}$ Thus, it is conceivable that in on hand the binding of RelA to the bax gene promoter might directly block p73 and RNA pol II recruitment through a mechanism of steric hindrance, as observed for RelAmediated repression of glucocorticoid-receptor-dependent transcription. $^{31}$ In another hand, RelA may repress p73mediated transcription by both sequestering the coactivator p300/CBP and favoring the recruitment of corepressor HDAC complexes (Figure 6d), as observed in other systems. ${ }^{20,21}$

CD28 is an important regulator of T-cell survival by inducing the expression of antiapoptotic proteins, in particular of Bcl-xL. ${ }^{28}$ Data from Bcl-xL-deficient mice indicate that $\mathrm{BCl}-\mathrm{xL}$ is essential for the survival of double-positive thymocyte but not mature $\mathrm{T}$ lymphocytes. ${ }^{32} \mathrm{We}$ have recently demonstrated that CD28 stimulation, in the absence of TCR, 
protects primary $\mathrm{T}$ cells from IR-mediated apoptosis by inducing RelA-dependent transcription of $b c l-x L .{ }^{16}$ Here, we demonstrate that CD28-delivered signals also inhibit p73induced bax expression in irradiated T cells, by interfering with p73 and RNA pol II recruitment on the promoter (Figure 2). These data evidence that CD28 is able to deliver a unique signal leading to the induction of survival factors and repression of proapoptotic genes.

A possible candidate in mediating CD28-protective signals is Akt. $^{22,23}$ Akt has been also described to inhibit Bax translocation to mitochondria following serum deprivation. ${ }^{33}$ Our data on the restoration of both IR-induced apoptosis and Bax levels in CD28-costimulated T cells treated with the PI3K inhibitor LY294002 reveal a further role of Akt in regulating Bax expression. Basu et al. $^{34}$ have recently reported that Akt phosphorylates the Yes-associated protein (YAP), thus impairing its nuclear translocation and inhibiting its function as strong transcriptional coactivator of p73. ${ }^{35}$ Thus, CD28mediated activation of Akt may lead to both the inactivation of YAP and the recruitment of RelA-containing repressor complexes ${ }^{31}$ on the bax gene promoter (Figure 7c), thereby completely blocking p73-mediated transcriptional activity.

\begin{abstract}
Materials and Methods
Cell lines, antibodies and reagents. Human primary $\mathrm{CD} 4^{+} \mathrm{T}$ cells were enriched from peripheral blood mononuclear cells (PBMCs) by MACS microbead sorting (Miltenyi Biotec, Milano, Italy) and cultured in RPMI 1640 supplemented with $5 \%$ human serum (Euroclone, UK), L-glutamine, penicillin and streptomycin (GibcoBRL, Grand Island, NY, USA). The purity of the sorted population was $95-99 \%$. The $\mathrm{CD}^{+}$Jurkat $\mathrm{T}$ cell line (clone J106.60) was maintained in RPMI 1640 supplemented with 10\% FCS, L-glutamine, penicillin and streptomycin (Gibco$B R L$ ). Murine $L$ cells and $L$ cells expressing human B7.1 (Dap/B7) were previously described. ${ }^{16}$ Anti-p65/RelA (C-20), anti-HA (Y11), anti-p73 (H-79), anti-p53 (DO-1), anti-Bax, anti-Akt and anti-RNA pol II Abs were purchased from Santa Cruz Biotechnology (Santa Cruz, CA, USA). Anti-p50 (06-886) and anti-p52 (05-361) Abs were purchased from Upstate Biotechnology (Lake Placid, NY, USA). The PI3K inhibitor LY294002 was from Calbiochem (La Jolla, CA, USA), TSA and the proteasome inhibitor MG101 were purchased from Sigma.
\end{abstract}

Plasmids, cell transfection and luciferase assays. pcDNA3expressing HA-tagged human $\mathrm{p} 73$ isoforms $(\alpha, \beta, \gamma, \delta), \Delta 84 \mathrm{p} 73 \alpha-\delta$ isoforms and FLAG-p53 have been previously described. ${ }^{2} \mathrm{HA}$-tagged p65/RelA and ReIB as well as p50 and p52 expression vectors were kindly provided by $G$ Natoli (Department of Experimental Oncology, European Institute of Oncology, Milan, Italy). HA-tagged Akt construct was kindly provided by T Mustelin (The Burnham Institute for Medical Research, La Jolla, CA, USA). Bax-luciferase reporter construct was obtained by subcloning the PCR-generated fragment $(-715$ to $-317 \mathrm{bp})$ from the bax gene promoter into BgNl-Hindlll sites of the pGL3-luciferase Enhancer vector (Promega). Mutp53- and Del- $\kappa \mathrm{B}$-luciferase mutants were derived from baxluciferase construct by substituting three nucleotides within the consensus p53binding sites $(-474$ to $-465 \mathrm{bp}),{ }^{10}$ and deleting the three NF- $\kappa$ B binding sites $(-708$ to $-502 \mathrm{bp}),{ }^{7}$ respectively, by PCR. The primers used were as follows: mutp53 5'-AAGTTAGAGATAATGCTGGGCGTAGG-3' and $5^{\prime}$-CCTACGCCCAG CATTATCTCTAACTT-3'; Del- $\kappa$ B $5^{\prime}$-ATTGGTACCATCTCTTGGGCTTCACAAG TTA- $3^{\prime}$ and $5^{\prime}$-TACCGGAATGCCAAGCTTACT- $3^{\prime}$. The entire sequences of the mutants were verified by DNA sequencing.

Jurkat cells were transiently transfected with the indicated expression vectors as previously described. ${ }^{36}$ Luciferase activity was measured according to the manufacturer's instruction (Promega). Transfection efficiency was controlled by coexpressing pEGFP (Clontech), encoding an eGFP. Luciferase activity determined in triplicates was expressed as fold induction over the basal activity of cells transfected with empty vectors and/or as arbitrary luciferase units after normalization to GFP values.
Semiquantitative PCR. The PCR mixture containing $50 \mathrm{mM} \mathrm{KCl}, 10 \mathrm{mM}$ Tris- $\mathrm{HCl}, 2.5 \mathrm{mM} \mathrm{MgCl}, 0.2 \mathrm{mM}$ dNTPs, $0.2 \mu \mathrm{M} \mathrm{5}$ and $3^{\prime}$ oligonucleotide primers and 2.5 $\mathrm{U}$ Taq polymerase (Perkin-Elmer, Cetus, Norwalk, CT, USA) was amplified in $0.5 \mathrm{ml}$ GeneAmp tubes in a final volume of $50 \mu \mathrm{l}$. PCR mixtures were amplified by 35 cycles at $94^{\circ} \mathrm{C}$ for $1 \mathrm{~min}, 60^{\circ} \mathrm{C}$ for $30 \mathrm{~s}$ and $72^{\circ} \mathrm{C}$ for $30 \mathrm{~s}$. PCR was conducted in the automated DNA Thermal Cycler GeneAmp PCR System 2400 (Perkin-Elmer). Primers sequences were as follows: BCl-xL $5^{\prime}$-ATTGGTGAGTCGGATCGCAGC-3' and $5^{\prime}$-AGAGAAGGGGGTGGGAGGGTA-3'; Bax 5'-ATGGTCACGGTCTGCCA-3' and $5^{\prime}$-GACCCGGTGCCTCAGGA-3'; Bim 5'-GAGAAGGTAGACAATTGCAG-3' and 5'-GACAATGTAACGTAACAGTCG-3'; Puma 5'-TGTAGAGGAGACAGGAATCC ACGG-3' and 5\%'-AGGCACCTAATTGGGCTCCATCTC-3' for GAPDH, specific primers have been previously described. ${ }^{16} \mathrm{PCR}$ products were size fractionated by agarose electrophoresis and normalized according to the amount of GAPDH detected in each sample.

p73 transcript analysis. To detect p73 splicing variant expression, radioactive RT-PCR was performed, as previously described, ${ }^{12}$ using the following primers: $5^{\prime}$-TTCTGCAGGTGACTCAGGCTG-3' for RT; and $5^{\prime}$-ACTT TGAGATCCTGATGAAG-3' (sense primer) and 5'-CAGATGGTCATGCGGTACTG-3' (antisense primer) for PCR amplification. CDNA synthesis was performed starting with equal concentration of RNA $(1 \mu \mathrm{g})$. Radioactive PCR was performed in $50 \mu \mathrm{l}$ of reaction buffer containing $5 \mu \mathrm{l}$ of the $\mathrm{RT}$ product, $50 \mathrm{mM} \mathrm{KCl}, 10 \mathrm{mM}$ Tris- $\mathrm{HCl}(\mathrm{pH}$ 9.0), $0.1 \%$ Triton $\mathrm{X}-100,1.5 \mathrm{mM} \mathrm{MgCl}_{2}$, dNTPs $0.2 \mathrm{mM}$ each, cold primers $0.4 \mu \mathrm{M}$ each, plus $40 \mathrm{nM}$ each of $\left[\gamma^{32} \mathrm{P}\right] \mathrm{dATP}$-labeled primers and $2.5 \mathrm{U}$ of Taq DNA polymerase. Amplifications consist of one cycle at $95^{\circ} \mathrm{C}$ for $5 \mathrm{~min}$ followed by 35 cycles at $95^{\circ} \mathrm{C}$ for $60 \mathrm{~s}, 59^{\circ} \mathrm{C}$ for $55 \mathrm{~s}$ and $72^{\circ} \mathrm{C}$ for $45 \mathrm{~s}$. PCR products were separated on a non-denaturating $6 \%$ polyacrylamide gel, dried and analyzed by autoradiography.

Immunoblotting. Protein extracts were obtained by lysing cells for $30 \mathrm{~min}$ at $4{ }^{\circ} \mathrm{C}$ in lysis buffer $(20 \mathrm{mM}$ Tris- $\mathrm{HCl}, \mathrm{pH} 7.5,150 \mathrm{mM} \mathrm{NaCl}, 1 \%$ Nonidet P-40 (NP-40), $0.5 \%$ NaDoc and $1 \%$ SDS) in the presence of protease and phosphatase inhibitors. Proteins were resolved by SDS-PAGE and blotted onto nitrocellulose membranes. Blots were incubated with the indicated primary antibodies, extensively washed and after incubation with horseradish peroxidase (HRP)-labeled goat anti-rabbit or goat anti-mouse Abs (Amersham Pharmacia), developed with the enhanced chemiluminescence's detection system (Amersham Pharmacia).

ChIP assays. ChIP assays were performed as previously described. ${ }^{16}$ Briefly, after fixing in $1 \%$ formaldehyde, cells were lysed for $5 \mathrm{~min}$ in $50 \mathrm{mM}$ Tris, $\mathrm{pH} 8.0$, $2 \mathrm{mM}$ EDTA, $0.1 \%$ NP- 40 and $10 \%$ glycerol supplemented with proteases inhibitors. Nuclei were resuspended in $50 \mathrm{mM}$ Tris, $\mathrm{pH} 8.0,1 \%$ SDS and $5 \mathrm{mM}$ EDTA. Chromatin was sheared by sonication, centrifuged and diluted 10 times in $50 \mathrm{mM}$ Tris, pH 8.0, 0.5\% NP-40, 0.2 M NaCl, 0.5 mM EDTA. After preclearing with a $50 \%$ suspension of salmon sperm-saturated protein $\mathrm{A}$, lysates were incubated at $4^{\circ} \mathrm{C}$ overnight with the indicated antibodies. Immune complexes were collected with sperm-saturated protein $A$, washed three times with high-salt buffer $(20 \mathrm{mM}$ Tris, $\mathrm{pH}$ 8.0, $0.1 \%$ SDS, $1 \% \mathrm{NP}-40,2 \mathrm{mM}$ EDTA, $500 \mathrm{mM} \mathrm{NaCl}$ ) and five times with $1 \times$ Tris/EDTA (TE). Immune complexes were extracted in $1 \times$ TE containing $1 \%$ SDS, and protein-DNA cross-links were reverted by heating at $65^{\circ} \mathrm{C}$ overnight. DNA was extracted by phenol-chloroform and about $1 / 20$ of the immunoprecipitated DNA was used in each PCR. The primers used were as follows: Bax promoter $5^{\prime}$-CCCGGGAATTCCAGACTGCAG-3' and $5^{\prime}$-GAGCTCTCCCCAGCGCAGAAG-3'; Bcl-xL promoter $5^{\prime}$-GCACCACCTACATTCAAATCC-3' and $5^{\prime}$-CGATGGAGGAGG AAGCAAGC- $3^{\prime}$. Puma promoter $5^{\prime}$-GAACGCCCGTCGGTCGGTCTGT-3' and $5^{\prime}$-CAAGTCAGGACTTGCAGGCGC-3'; $\triangle$ Np73 promoter $5^{\prime}$-CTCCTCTCCATGCA GCCCTTGGAC- $3^{\prime}$ and $5^{\prime}$-CCAACAACAAAACCCGCGGCCCAC- $3^{\prime}$.

Apoptosis analysis. Human $\mathrm{CD} 4^{+} \mathrm{T}$ cells were exposed to $5 \mathrm{~Gy}$ of IR by using an X-ray apparatus ( $A L$ filter $3 \mathrm{~mm}$ ) and then cultured in the presence (B7) or absence (ctr) of adherent Dap/B7 cells for $24 \mathrm{~h}$. Where indicated cells were pretreated for $2 \mathrm{~h}$ with either LY294002 $(50 \mu \mathrm{M})$ or TSA $(100 \mathrm{nM})$ or MG101 $(10 \mu \mathrm{M})$ before IR. At the end of incubation, cells were carefully resuspended in PBS containing $0.1 \%$ Triton X-100 (Sigma) and $100 \mathrm{U} / \mathrm{ml}$ RNase A (Sigma), were stained with $50 \mu \mathrm{g} / \mathrm{ml}$ propidium iodide (PI; Sigma) and incubated at $37^{\circ} \mathrm{C}$ for $15 \mathrm{~min}$. Apoptosis was analyzed by a BD Biosciences FACScalibur (BD Biosciences, Mountain View, CA, USA), by a biparametric analysis of FL2-H versus SSC- $\mathrm{H}$ graphs. Cells showing a less than $2 \mathrm{C}$ DNA content (hypodiploid cells) and high SSC-H (granular, highly condensed cells) were regarded as apoptotic. The mean 
frequencies of apoptotic cells were calculated at least from three independent experiments and statistically analyzed using Student's $t$-test. The percentage of specific apoptosis was calculated as follows: $\%$ specific apoptosis $=100 \times(\% \mathrm{PI}+$ cells $-\%$ spontaneous $\mathrm{PI}+$ untreated cells $) /(100-\%$ spontaneous $\mathrm{PI}+$ untreated cells).

siRNA transfection. $\mathrm{p} 73$ siRNA and Bax sMART pool siRNA oligonucleotides were purchased from Dharmacon (Chicago, IL, USA) and designed on the sequence of human p73 cDNA encoding the DNA-binding domain (siRNA p73) or GFP (siRNA ctr). The sense strand sequences of the siRNAs were as follows: $p 73$ $5^{\prime}$-CCAUCCUGUACAACUUCAUGUG- ${ }^{\prime}$ and GFP $5^{\prime}$-GTTCAGCGTGTCCGG CGAG-3'. The two siRNAs specific for p53 (A and B) were kindly provided by $G$ Blandino (Department of Experimental Oncology, Regina Elena Cancer Institute Rome, Italy) and sequences are available upon request.

Primary T-cell blasts were isolated by MACS microbead sorting from PBMCs activated for 4 days with $1 \mu \mathrm{g} / \mathrm{ml}$ phytohemagglutinin and $5 \mathrm{IU} / \mathrm{ml}$ recombinant IL-2 (Roche). Cationic lipid complexes, prepared by incubating $5 \mu \mathrm{g}$ of indicated siRNA with $10 \mu$ lipofectamine (Invitrogen) in $600 \mu \mathrm{l}$ Optimem (Invitrogen) for $1 \mathrm{~h}$, were added to $10^{7} \mathrm{~T}$-cell blasts in a final volume of $5 \mathrm{ml}$. After overnight incubation, cells were washed and cultured in RPMI containing $1 \% \mathrm{FCS}$ for further $24 \mathrm{~h}$. At the end of incubation, p73 expression was analyzed by western blotting, and T cells were exposed to $5 \mathrm{~Gy}$ IR and after $24 \mathrm{~h}$ apoptosis was evaluated by PI staining.

Acknowledgements. We thank Dr. Gioacchino Natoli for insightful discussions and reagents, and Dr. Thomas Mustelin and Dr. Giovanni Blandino for reagents. This research is supported by grants from the Italian Association for Cancer Research (AIRC), the Ministry of University and Research (MIUR-PRIN) and the 'Istituto Pasteur Fondazione Cenci Bolognetti,' University of Rome 'La Sapienza.' AC and ML are supported by grants from the European Commission (FP6 'Active p53' Consortium). BM is supported by a FIRC fellowship.

1. Opferman JT, Korsemeyer SJ. Apoptosis in the development and maintenance of the immune system. Nat Immunol 2003; 5: 410-415.

2. Antonsson B, Conti F, Ciavatta A, Montessuit S, Lewis S, Martinou I et al. Inhibition of Bax channel-forming activity by Bcl-2. Science 1997; 277: 370-372.

3. Schlesinger PH, Gross A, Yin XM, Yamamoto K, Saito M, Waksman G et al. Comparison of the ion channel characteristics of proapoptotic BAX and antiapoptotic BCL-2. Proc Natl Acad Sci USA 1997; 94: 11357-11362.

4. Cheng EH-YA, Wei MC, Weiler S, Flavell RA, Mak TM, Lindsten T et al. BCL-2, BCL-XL sequester $\mathrm{BH} 3$ domain-only molecules preventing $\mathrm{BAX}$ and $\mathrm{BAK}$-mediated mitochondria apoptosis. Mol Cell 2001; 8: 705-711.

5. Verma IM, Stevenson JK, Scharz EM, van Antwerp DV, Miyamoto S. Rel/NF- $\kappa \mathrm{B} / \|_{\kappa} \mathrm{B}$ family: intimate tails of association and dissociation. Genes Dev 1995; 9: 2723-2735

6. Karin M, Ben-Neriah Y. Phosphorylation meets ubiquitination: the control of NF-kappaB activity. Annu Rev Immunol 2000; 18: 621-623

7. Bentires-Alj M, Dejardin E, Viatour P, Van Lint C, Froesch B, Reed JC et al. Inhibition of the $\mathrm{NF}-\kappa \mathrm{B}$ transcription factor increases Bax expression in cancer cell lines. Oncogene 2001; 20: $2805-2813$

8. Grimm T, Scheider S, Naschberger E, Huber J, Guenzi E, Keiser A et al. EBV latent membrane protein-1 protects B cells from apoptosis by inhibition of BAX. Blood 2005; 105 3263-3269.

9. Levrero M, De Laurenzi V, Costanzo A, Gong J, Wang JY, Melino G. The p53/p63/p73 family of transcription factors: overlapping and distinct functions. J Cell Sci 2000; 113 $1661-1670$.

10. Miyashita T, Reed JC. Tumor suppressor p53 is a direct transcriptional activator of the human bax gene. Cell 1995; 80: 293-299.

11. Kaeser MD, Iggo RD. Chromatin immunoprecipitation analysis fails to support the latency model for regulation of p53 DNA binding activity in vivo. Proc Natl Acad Sci USA 2002; 99 95-100.
12. De Laurenzi V, Costanzo A, Barcaroli D, Terrinoni A, Falco M, Annicchiarico-Petruzzelli M et al. Two new p73 splice variants, gamma and delta, with different transcriptional activity. J Exp Med 1998; 188: 1763-1768.

13. De Laurenzi V, Catani MV, Terrinoni A, Corazzari M, Melino G, Costanzo A et al. Additional complexity in p73: induction by mitogens in lymphoid cells and identification of two splicing variants epsilon and zeta. Cell Death Differ 1999; 6: 389-390.

14. Lissy NA, Davis PK, Irwin M, Kaelin WG, Dowdy SE. A common E2F-1 and p73 pathway mediates cell death induced by TCR activation. Nature 2000; 407: 642-645.

15. Wan YY, DeGregori J. The survival of antigen-stimulated $T$ cells requires NF- $\kappa$ B-mediated inhibition of 73 expression. Immunity 2003; 18: 331-342.

16. Marinari $B$, Costanzo A, Marzano V, Piccolella E, Tuosto $L$. CD28 delivers a unique signal leading to the selective recruitment of RelA and $\mathrm{p} 52$ nuclear factor-kappaB subunits on IL-8 and Bcl-XL gene promoters. Proc Natl Acad Sci USA 2004; 101: 6098-6103.

17. Gong JG, Costanzo A, Yang HQ, Melino G, Kaelin Jr WG, Levrero $M$ et al. The tyrosine kinase c-Abl regulates $\mathrm{p} 73$ in apoptotic response to cisplatin-induced DNA damage. Nature 1999; 399: 806-809.

18. Yuan ZM, Shioya $H$, Ishiko $T$, Sun $X, G u J$, Huang $Y Y$ et al. $p 73$ is regulated by tyrosine kinase c-Abl in the apoptotic response to DNA damage. Nature 1999; 399: 814-817.

19. Melino G, De Laurenzi V, Vousden KH. p73: friend or foe in tumorigenesis. Nat Rev Cancer 2002; 2: 605-615.

20. Campbell KJ, Rocha S, Perkins ND. Active repression of antiapoptotic gene expression by RelA(p65) NF- $\kappa$ B. Mol Cell 2004; 13: 853-865.

21. Vasudevan KM, Gurumurthy S, Rangnekar VM. Suppression of PTEN expression by NF-kappa B prevents apoptosis. Mol Cell Biol 2004; 24: 1007-1021.

22. Jones RG, Parsons M, Bonnard M, Chan VS, Yeh WC, Woodgett JR et al. Protein kinase B regulates $T$ lymphocyte survival, nuclear factor kappaB activation, and $\mathrm{Bcl}-\mathrm{X}(\mathrm{L})$ levels in vivo. J Exp Med 2000; 191: 1721-1734.

23. Kane LP, Andres PG, Howland KC, Abbas AK, Weiss A. Akt provides the CD28 costimulatory signal for up-regulation of IL-2 and IFN-gamma but not TH2 cytokines. Nat Immunol 2001; 2: 37-44.

24. Rathmell JC, Lindsten T, Zong W-X, Cinalli RM, Thompson CB. Deficiency in Bak and Bax perturbs thymic selection and lymphoid homeostasis. Nat Immunol 2002; 3: $932-939$

25. Villunger A, Michalak EM, Coultas L, Mullauer F, Bock G, Ausser Lechner MJ et al. p53and drug-induced apoptotic responses mediated by $\mathrm{BH} 3-$ only proteins puma and noxa. Science 2003; 302: 1036-1038.

26. Lowe SW, Schmitt EM, Smith SW, Osborne BA, Jacks T. p53 is required for radiationinduced apoptosis in mouse thymocytes. Nature 1993; 362: 847-849.

27. Senoo M, Manis JP, Alt FW, McKeon F. p63 and p73 are not required for the development and p53-dependent apoptosis of T cells. Cancer Cell 2004; 6 : 85-89.

28. Khoshnan A, Tindell C, Laux I, Bae D, Bennett $B$, Nel AE. The NF- $\kappa B$ cascade is important in $\mathrm{Bcl}-\mathrm{xL}$ expression and for the anti-apoptotic effects of the $\mathrm{CD} 28$ receptor in primary human $\mathrm{CD}^{+}$lymphocytes. J Immunol 2000; 165: 1743-1754.

29. Strasser A, Harris AW, Huangh DC, Krammer PH, Cory S. Bcl-2 and Fas/APO-1 regulate distinct pathways to lymphocyte apoptosis. EMBO J 1995; 14: 6136-6147.

30. Van Parijs L, Peterson DA, Abbas AK. The Fas/Fas ligand pathway and Bcl-2 regulate $T$ cell responses to model self and foreign antigens. Immunity 1998; 8: 265-274.

31. Burkhart BA, Hebbar PB, Trotter KM, Archer TK. Chromatin-dependent E1A activity modulates NF-kappaB RelA-mediated repression of glucocorticoid receptor-dependent transcription. J Biol Chem 2005; 25: 6349-6358.

32. Chao DT, Korsemeyer SJ. Bcl-xL-regulated apoptosis in t cell development. Int Immunol 1997; 9: 1375-1384.

33. Tsuruta F, Masuyama N, Gotoh Y. The phosphatidylinositol 3-kinase (PI3K)-Akt pathway suppresses Bax translocation to mitochondria. J Biol Chem 2002; 277: 14040-14047.

34. Basu S, Totty NF, Irwin M, Sudol M, Downward J. Akt phosphorylate the Yes-associated protein, YAP, to induce interaction with 14-3-3 and attenuation of p73-mediated apoptosis. Mol Cell 2003; 11: 11-23.

35. Strano S, Monti O, Pediconi N, Baccarini A, Fontemaggi G, Lapi E et al. The transcriptional coactivator Yes-associated protein drives p73 gene-target specificity in response to DNA damage. Mol Cell 2005; 18: 447-449.

36. Piccolella E, Spadaro F, Ramoni C, Marinari B, Costanzo A, Levrero M et al. Vav-1 and the $I K K \alpha$ subunit of $I \kappa B$ kinase (IKK) functionally associate to induce nuclear factor- $\kappa \mathrm{B}$ activation in response to CD28 engagement. J Immunol 2003; 170: 2895-2903.

\section{Supplementary Information accompanies the paper on Cell Death and Differentiation website (http://www.nature.com/cdd)}

